\title{
Law Enforcement Agencies which Respond to Nationally Significant Crime ALASTAIR M MILROY
}

The purpose of this chapter is to present the uncertainty of investigating and responding to nationally significant crime from a law enforcement agency perspective and to use that perspective to comment on the other chapters. Responding to national crime threats involves a multitude of agencies, but my knowledge and experience is predominately law enforcement related and this paper is from that viewpoint.

The paper is practical and describes four major uncertainties that I was confronted with at the Australian Crime Commission in responding to nationally serious crime. The paper acknowledges there is no scientific method to achieve a successful outcome against serious crime.

To demonstrate the uncertainties of responding to crime I have used 'illicit drugs' as a nationally significant crime type and an Asian criminal drug syndicate as an example of a special investigation throughout the paper to highlight the issues for the law-makers (governments), the law enforcement decision-makers (Commissioners of Police and Chief Executive Officers of law enforcement agencies) and the law enforcement agencies that investigate the crimes.

The four uncertainties listed below are by no means the only uncertainties dealt with by the Australian Crime Commission or law enforcement agencies in responding to serious crime.

\section{Four major uncertainties}

1. What nationally significant crimes should the Australian Crime Commission pursue in accordance with the Australian Crime Commission Act 2002?

2. Will government and the Australian Crime Commission Board support the crimes identified by the Commission for a law enforcement response?

3. Will the Australian Crime Commission have the capabilities to impact on the nationally significant crimes identified?

4. Will the operational results meet stakeholder expectations? 
My approach and predisposition to responding to serious crime is governed by my background and experiences as a detective and police officer. My ideas and thoughts are not supported by rigorous research but reflect my experience in the context of thirty-seven years in state, federal and international law enforcement activities. Much of the insight in this paper stems from the period I spent as Chief Executive Officer at the Australian Crime Commission from 2003 to 2009.

The Australian Crime Commission is a statutory body working nationally with a range of federal, state and territory agencies in partnership to counter serious and organised crime. The commission was established to address federally relevant criminal activity, which is defined in Section 4 of the Australian Crime Commission Act 2002 as:

- an offence against a law of the commonwealth or a territory; or

- an offence against a law of a state that has a federal aspect.

In practical terms, federally relevant criminal activity generally equates to 'serious and organised crime'.

The governance framework for the Australian Crime Commission is extensive and includes the Minister for Home Affairs, the Inter-Governmental Committee (commonwealth, state and territory police/justice ministers), the Parliamentary Joint Committee (members of the Senate and House of Representatives), the Australian Commission for Law Enforcement Integrity and the Australian Crime Commission Board.

The Australian Crime Commission Board, which is chaired by the Commissioner of the Federal Police, consists of eight state and territory police commissioners and five commonwealth agency heads being: The Director General of the Australian Security and Intelligence Organization, the Chair of the Australian Securities and Investment Commission, the Chief Executive Officer of Customs, the Secretary of the Attorney-General's Department and the Chief Executive Officer of the Australian Crime Commission who is the only non-voting member.

The aim of the Australian Crime Commission is to bring together all arms of law enforcement intelligence gathering to unite the fight against serious criminal activities. A primary objective of the Australian Crime Commission in partnership with other law enforcement agencies is to disrupt significant criminal groups and individuals by arrest, seizure of illegal drugs, firearms and proceeds of crime action. Simultaneously the Australian Crime Commission acts to break down criminal behaviour and the continuity of the criminal enterprise. 


\section{What nationally significant crimes?}

The first uncertainty for the Australian Crime Commission is to identify nationally significant crimes that should be pursued in accordance with the Australian Crime Commission Act 2002. As Sue Wilkinson (2010) described in her chapter, in Australia organised crime is acknowledged as a key part of the national security statement and strategy. The Australian Crime Commission Act interprets the meaning of 'serious and organised crime', describing it as involving two or more offenders, involving substantial planning and organisation; using sophisticated methods and techniques; committed in conjunction with other offences of a like kind; and a serious offence within the meaning of the Proceeds of Crime Act 2002 (Australian Crime Commission Act 2002).

The true extent and nature of nationally serious and organised crime in Australia is relatively uncertain. As Sue Wilkinson (2010) highlights, '[o]rganised crime does not necessarily follow a logical process, a plan'.

Law enforcement is uncertain about the number of nationally significant criminals or criminal groups that are operating within Australia. A recent Parliamentary Joint Committee Inquiry heard that there is limited agreement over how serious and organised crime should be defined (Schloenhardt 2009). For example, the Australian Institute of Criminology refers to organised crime as usually being a structured group of three or more people that exists over a period of time with the aim of committing serious crime offences with profit as a motive (Australian Institute of Criminology 2004).

The Australian Crime Commission's main functions under the Act involve collecting, correlating, analysing and disseminating criminal intelligence and information. This intelligence function is the basis of the threat and harm assessment processes. The Australian Crime Commission undertakes the threat assessment process to consider the impact of a range of nationally significant criminal issues and activities on Australian interests. The threat assessment process informs law enforcement decision-makers and aids their process of determining and prioritising national criminal law enforcement efforts and targets.

The Australian Crime Commission Board provides strategic direction and determines the national criminal intelligence priorities. The decisions by board members of priorities and measures to respond to serious and organised crime can differ due to varying jurisdictional concepts of serious and organised crime, different political pressures and conflicting agendas.

As Carmen Lawrence (2010) indicates in her chapter, what is defined as crime in legislation and how crimes are depicted are essentially political decisions. Similarly, the priority given to the detection and prosecution of various crimes 
and the resources devoted to these tasks are dependent on the perceptions that politicians and their advisors have of the risks to the public - and to their own political futures - posed by those crimes. Perhaps, as Kempton (1998, cited in the chapter by Richard Jarrett and Mark Westcott 2010) suggests, if government members and other decision-makers were better educated in interpreting risks they would be less dependent on their perceptions of the law and order risks to the community. We need research on how to teach decision-makers interpretive estimates and how to encourage them to apply the methodology to their decision-making.

In summary, how serious and organised crime is defined determines, to an extent, how serious and organised crime will be approached (Parliamentary Joint Committee on the Australian Crime Commission 2009).

\section{Support by management board}

The presentation to the Australian Crime Commission Board of suitable criminal groups for a law enforcement response comes with its own uncertainties.

Inconsistencies in reporting and intelligence data retrieval methodologies prevent accurate assessment of the nature and extent of serious crime. The absence of a nationally coordinated database prevents the collection and exchange of information, intelligence, advice and warnings between key stakeholders. Using police data to compile national statistics comes with incompatible data sets and as a consequence the statistics can lack parity.

This comment finds support in Robyn Attewell's (2010) chapter. She highlights that, despite the wide availability of administrative police databases and survey information, both nationally and internationally, these empirical sources are limited by problems of scope and coverage, and inconsistent definitions across jurisdictions. Attewell argues that often there is no data to work with, either 'events are sparse (terror attacks), difficult to classify consistently (disruption of organised crime activity), difficult to detect (people smuggling), there are no complainants (drug trafficking and organised crime) or the data are generally only accessible through liaison with other agencies (cyber-crime, drug importation)'.

Establishing that a crime group is worthy of a special investigation must meet legislative requirements and the threshold of 'whether ordinary police methods of investigation into the matters are likely to be effective' (Australian Crime Commission Act 2002, 7C (3)). The Australian Crime Commission is required to prove to the Australian Crime Commission Board that traditional police methods have been ineffective based on an incomplete intelligence collection process. 
To provide insight into the differing views of law enforcement, a submission to an Australian Parliamentary Joint Committee inquiring into the future impact of serious and organised crime on Australian society disclosed a lack of uniformity by the nine law enforcement agencies. These agencies were asked to identify the current and future threats by organised crime groups. Only one type of crime - 'illicit drugs' — was common to every agency as a threat. The submissions identify that there are differences in opinion about how organised crime is to be countered and that serious crime in one jurisdiction may not have the same degree of influence in another jurisdiction (Sullivan 2007).

Defining and assessing significant national criminals is based on information and intelligence systems that have inconsistencies. As a result there are no assurances that the governments involved and/or the Australian Crime Commission Board will support the actions suggested by the Australian Crime Commission for action.

On most occasions if the law enforcement decision-makers agree to collaborate against a nationally significant criminal group there is usually an obligation to commit resources and funds to achieve a positive outcome for the Australian community. Commissioners of Police constantly argue insufficient police numbers, high employee attrition rates and insufficient annual appropriations to conduct business. Police unions agree and argue poor police-to-population ratios.

The pressures on police budgets are highlighted by the increasing importance of outside sources of revenue to police agencies, despite real increases in the budgets of many police jurisdictions.

The tightening of police budgets clearly has implications for police responses, both in relation to dealing with law and order, and in respect of the way in which police organizations are managed. It affects police priorities and how low priority tasks are dealt with (Ayling et al. 2009, p. 17-18).

Some, such as Lawrence (2010), argue that the widely exaggerated perceptions of risk of crimes, generated through fear campaigns, have inevitably distorted law and justice policies and misdirected public expenditure.

It is necessary in practice to find a balance between the expectations of governments, law enforcement decision-makers, commentators and the community on crime reduction and the reality of insufficient police resources, funding and legislation. 


\section{Capabilities to impact on nationally significant crime}

Without the support of state, territory and federal police forces and other law enforcement agencies, the Australian Crime Commission's capabilities to respond to significant crime would be limited to its in-house resources. The appropriate capabilities mix required to impact on a national or transnational target is extensive. Developing a response capability without appreciating the full extent and nature of the criminal activities can have resource implications and influence the effectiveness of the intelligence operation or investigation.

Even with thorough information gathering by the Australian Crime Commission and presentation of a detailed picture of criminal group/s activities, there are still gaps in intelligence relating to the criminal identities and their methods. By using the example of the Asian drug syndicate it is possible to highlight the uncertain lines of inquiry that exist at the commencement of a national investigation and the difficulties of determining the resources required to impact on a criminal group.

\section{Asian drug syndicate-uncertainties and gaps in intelligence}

- extent of the global illicit drug distribution network

- harm caused by the illicit drug criminal network on the Australian community

- identity of the overseas principals

- methodologies used to source and transport illicit drugs into Australia

- preferred illicit drugs types

- volume of illicit drugs imported and distributed within Australia

- distribution networks throughout Australia

- identity of network members

- number of Australian based syndicates ordering and distributing illicit drugs

- geographical areas of operation within Australia

- methods for ordering illicit drugs and payment

- identity of local and/or overseas officials facilitating the illicit drug importations

- extent of money laundering and methodologies

- identity of the money facilitators

- types of technology used to facilitate crimes

- history of attempts to disrupt the syndicate by local and overseas police 
- extent of intelligence and information held by law enforcement agencies

- the level of cooperation that could be expected from overseas and local law enforcement agencies.

In relation to the Asian drug syndicate, sufficient intelligence and agreed priorities by Australian Crime Commission Board members allowed a national task force capability to be formed to disrupt the activities of the criminal syndicate. Building a case for a whole of law enforcement response is impeded by uncertainties and inconsistencies including lack of common legislation, as well as differing interoperability standards, skill competencies, police powers and procedures, criminal codes, information sharing protocols, jurisdiction management and cultural issues, to name a few.

Coordination and cooperation of the national task force involves utilising the resources from state and federal government agencies. The formation of the task force is based on the knowledge and assessment of current criminal activities, the type of operation to be conducted, proposed tactics, coercive powers, time frames, geographical locations, available funds and skills required to achieve the objectives of the investigation.

Formation of a task force to deal with the Asian drug syndicate involved nine agencies collaborating, including the Australian Crime Commission, Victoria Police, New South Wales Police, New South Wales Crime Commission, Western Australia Police, Austrac, Australian Taxation Office, Australian Customs Service and the Australian Federal Police.

If law enforcement agencies do not work together there is the potential to work against each other. Turf wars between state and federal agencies are common with the sharing of information and intelligence both locally and overseas complicated due to lack of trust and long-standing police cultural barriers. A response by multiple agencies can exacerbate jealousies and conflicts over who has jurisdiction - who is in command - or it can produce 'buck passing' where no agency wants to take responsibility. Lack of cooperation can mean crimes remain unsolved and criminals remain free to commit further offences (Prenzler 2009).

Prenzler (2009, p. 43) also highlights that the International Association of Chiefs of Police Code requires that 'police officers will cooperate with all legally authorised agencies and their representatives in the pursuit of justice'. In practice the Chiefs of Police Code is not always the behaviour displayed by law enforcement officers. 
There are always many issues to overcome to achieve success from crossjurisdictional task forces. As Wilkinson (2010) points out, it is often said that criminals take advantage of borders and jurisdictional barriers but police are hampered by them.

Uncertainty is an inescapable ingredient of investigating crimes, as there are many ways to tackle a crime problem. The task force involved in the Asian crime syndicate investigation involved sworn and unsworn investigators, physical and electronic surveillance operatives, analysts, accountants, lawyers and support staff drawn from the contributing agencies.

The jealousies that can exist between agencies can also exist between the various professionals assigned to the task force. Investigative cultures can isolate individuals into silos, which can impede cooperation, information sharing and impact on the ultimate success of the task force investigation (Dean and Gottschalk 2007).

Once the investigation was commenced, the Asian task force was confronted with information and intelligence that had omissions, duplications, gaps, classification restrictions, qualified releases and poor information sharing practices. The uncertainty associated with not enough information versus too much information is an interesting concept for law enforcement decisionmakers. In his chapter, Michael Smithson (2010) provides examples of where additional information increases uncertainty by creating conflict or being irrelevant. This is true. Each additional piece of information in an investigation has the capacity to be in conflict with information already gathered or it can be irrelevant. However, the benefit of gathering information and the associated intelligence process also assists in reducing that uncertainty (Longford 2008). Disinformation, deception, incorrect information, walls of silence, Chinese whispers, miscommunications and secrecy are all features of the intelligence gathering and investigative phases for joint agency task forces. The methods used by intelligence officers and investigators to identify a trend or explain the trend, highlight the risks, as well as identify the alternatives and gaps, are all processes used to reduce uncertainty in an investigation.

There was compulsory regular reporting of operational results, legal compliance, use of coercive powers, professional integrity, and resource usage to the Inter-Governmental Committee, the Parliamentary Joint Committee and the Australian Crime Commission Board. The release of sufficient information to inform decision-makers without compromising ongoing operations is a tricky balancing act. Providing written reports and operational updates involves managing sensitive data among many individuals with different agendas. 
Management of the media is never certain; editors control headlines and dull headlines do not sell newspapers. The media have an obligation to inform the community and governments want to appear active in reducing crime and catching criminals. If not properly managed, the media can engender fear, distort the facts and betray confidences. The media can exaggerate the risks the community actually face and clamour for an instant response, especially from government, to threats that may never materialise. Health and crime risks in particular are often distorted and politicians often join in (Lawrence 2010).

During the task force operation, when substantial seizures or arrests were made, relevant information was released to the media usually through the minister's office. Cross-jurisdictional agency media releases involving ministers and law enforcement agency heads at times can fail due to grandstanding and not recognising the efforts of all agencies involved. A media release can be reported by the media in line with their agenda and as Lawrence (2010) suggests politicians can line up beside senior police to give them (the politicians) greater credibility.

\section{Operational results and stakeholder expectations}

In February 2009, after a two-year investigation, the full results of the task force were made public. The task force investigated 26 cases of money laundering and 72 criminals were charged involving 139 charges. Sixteen criminal syndicates were disrupted and over $\$ 1$ billion worth of illicit drugs and drug making chemicals were removed from Australian streets. In business financial terms, the government's investment in this task force and special investigation translated to a rate of return of $6500 \%$, but who can put a real value on removing that amount of drugs from the community? This question is supported by Wilkinson (2010) who states the harm caused by organised crime is often insidious and hard to quantify. I indicated in a media release in 2009 that the greatest return for the government dollar and for the community is to solve crime as effectively and efficiently as possible.

This investigation highlighted to governments and the Australian Crime Commission Board the methods used by money laundering criminals to channel funds to overseas locations. Like all successful investigations, the intelligence and knowledge gained on the global and national criminal network caused a shift in law enforcement methods used to attack similar criminal networks.

Based on the original uncertainties and gaps in this investigation, the extent of the results for governments and partnering law enforcement was seen as 
extremely successful. While the task force followed the investigative plan, met key performance indicators, stayed within budget, achieved substantial arrests and charges, the overall impact on serious crime will never be known.

Uncertainty in police investigation is time consuming. In an investigation, uncertainty extends the investigation period, but at the same time- because of the uncertainty - the investigator/s are required to look further and to be more thorough. The saying 'the more you know the more you don't know' is very true; however, uncertainty can enhance both the intelligence and investigative process.

Ultimately the task force must present sufficient evidence to convict the Asian criminal syndicate and convince a judge and jury that a maximum sentence is appropriate. As Carmody (2010) highlights in his chapter 'juries are a source of unpredictability' and 'there is no way of forecasting how different juries will view the same set of facts'. Is it possible to know the truth about a crime and if all the evidence has been gathered? Carmody suggests that criminal litigation is at the mercy of luck where neither greater knowledge not superior skill guarantee success in every case. Nor does better preparation.

Questions of ethical behaviour by officers and/or noble cause corruption can be raised in relation to any investigation. Is a full confession by a criminal the truth, or has it been toned down to reduce the impact of the penalty? Are the witnesses credible or have the investigators confused facts with fiction, created biases or acted on hunches, theories and/or mindsets.

As Mark Kebbell, Damon Muller and Kirsty Martin (2010) point out in their chapter, ensuring task force team members have appropriate training and awareness of cognitive biases could mitigate some of these concerns. However, answers to these questions are all part and parcel of the prosecution process and are uncertainties that may present in the next stage of the law enforcement cycle.

\section{Managing uncertainties more effectively}

In Table 1, I summarise the key intersections with the other chapters in the book, along with critical areas that warrant further research. I describe some of these in more detail here, as well as raising other issues related to uncertainty that require research and practice attention.

One of the key uncertainties that law enforcement faces in combating serious and organised crime is collecting statistics about and mapping trends in organised crime due to the difficulties in defining and measuring organised crime. Even 
with cooperation from all law enforcement agencies, an accurate picture of the scale of serious criminal activity is difficult to ascertain, as private sector victims can be reluctant to declare their losses or may even treat losses as a bad debt.

For the decision-makers, including myself, the uncertainties exist in the lack of a national uniform intelligence database on crime trends to support our decisions to pursue one crime type over another and to determine the most urgent policing priority for the community. Such a national system needs agreed information and intelligence sharing protocols that would assist in producing a more accurate national picture of organised crime within Australia. Research that identifies a standardised classification system for crime that is acceptable both nationally and internationally would benefit future decision-makers. Further, a national uniform intelligence database would see the full benefits of the available statistical tools that Attewell (2010) describes in her chapter.

Even with an improved crime classification system for information and intelligence, there would need to be enhanced decision-making skills for determining future policing priorities. Although a threat and risk assessment methodology was used at the Australian Crime Commission to identify strategic and operational priorities, there can still be disagreement on the importance of the different types of criminal harm within a geographical region or relative to another region. Richard Jarrett and Mark Westcott (2010) provide an example of how risk scores can be used for a range of hazards that are geographically dispersed and of different types. They suggest having defined consequences, likelihood and risk scores, which allow risks to be combined to produce an interpretable result. Improving the skills of decision-makers by providing them with new tools such as interpretative estimates of risk is another area conducive to future research.

Greater awareness of the decision-making process can also be achieved by exposing decision-makers to the type of arguments presented by Smithson (2010) in his chapter. These include the impacts on a decision of the number of alternatives or outcomes, that reducing uncertainty is not always worthwhile, that more information can increase uncertainty, and that the right analytical tool is required to make decisions. Raising decision-maker awareness of biases as suggested by Kebbell and his colleagues (2010) is another opportunity to improve the decision-making process for law enforcement.

Nevertheless, the fact that the national task force was formed and achieved substantial results proves serious crime can be impacted upon in a coordinated manner in spite of jurisdictional differences, flawed decision-making, gaps and uncertainties in the national information and intelligence framework. The differing legislative tools, including criminal laws, proceeds of crime and variety of police powers, increase the complexity for the decision-makers in 
supporting a law enforcement response to serious crime. Impacting on serious and organised crime is a complex composite of policy and intelligence issues that are beyond the capacity of any one jurisdiction or agency. Harmonisation of law enforcement efforts can reduce displacement of criminal activities to other jurisdictions.

In investigating this particular syndicate it is not possible to guarantee that the Australian Crime Commission task force detected all criminals involved within Australia and overseas. If a method to quantify harm of organised crime on the community had been available, the Australian Crime Commission could have measured its performance more precisely. Successful drug law enforcement disrupts market supply creating a void for the re-emergence of criminal groups. If that void is filled by a new criminal group the uncertainty cycle starts again and law enforcement agencies must attempt to identify the methods that the new criminals have adapted to defeat the laws. 
Law Enforcement Agencies which Respond to Nationally Significant Crime

\begin{tabular}{|c|c|c|c|c|c|c|}
\hline 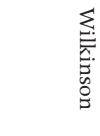 & $\begin{array}{l}\stackrel{0}{E} \\
\stackrel{5}{0} \\
\stackrel{0}{g}\end{array}$ & 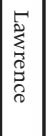 & 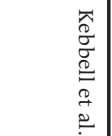 & 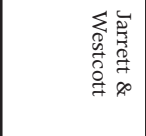 & 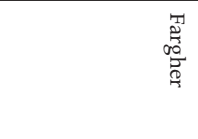 & $\stackrel{P}{*}$ \\
\hline 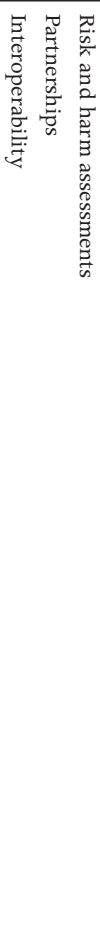 & 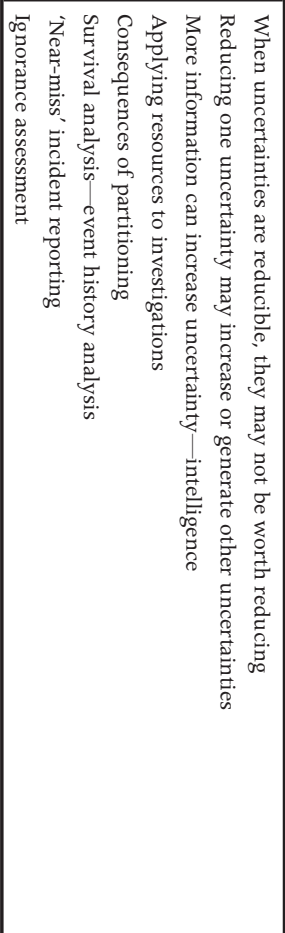 & & 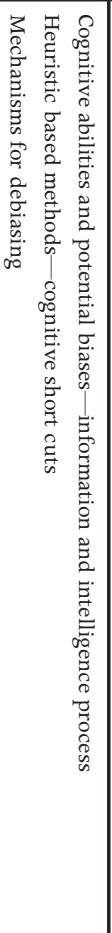 & 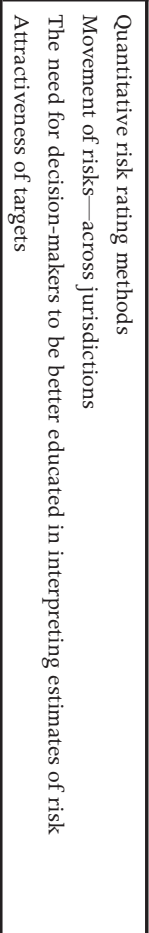 & 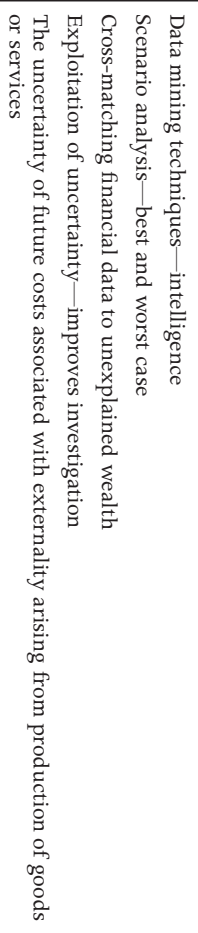 & 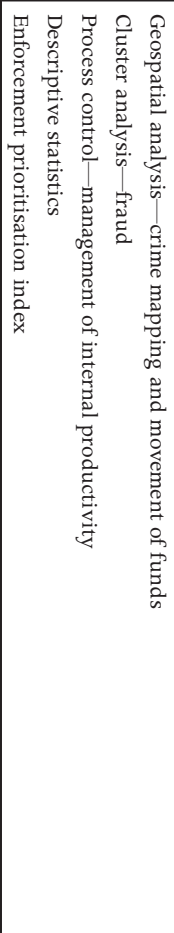 \\
\hline 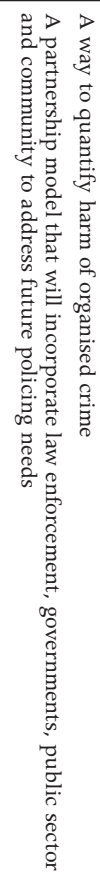 & 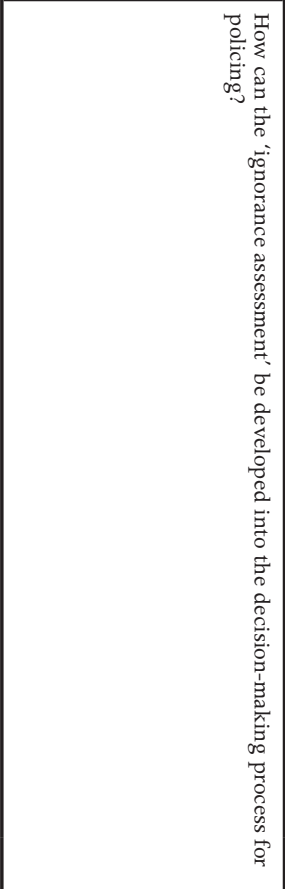 & 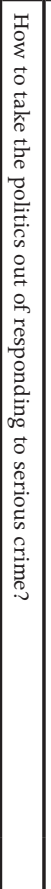 & 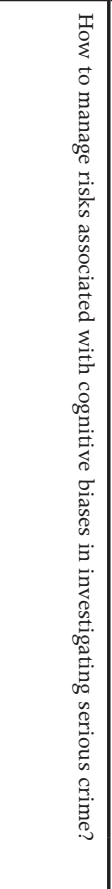 & 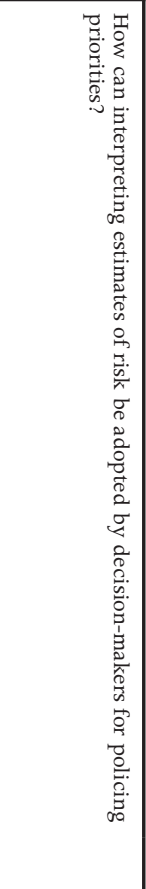 & 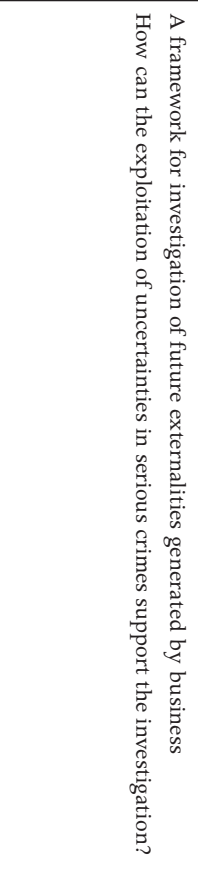 & 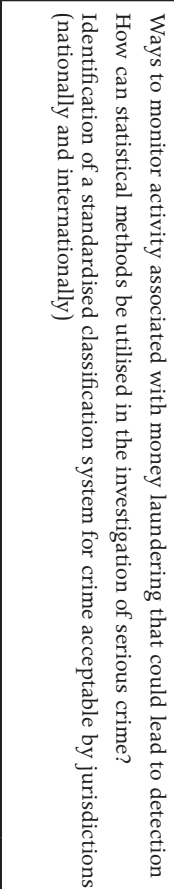 \\
\hline
\end{tabular}


Dealing with Uncertainties in Policing Serious Crime

\section{References}

Attewell, R 2010, 'Can statistics help', in G Bammer (ed.), Dealing with uncertainties in policing serious crime, ANU E Press, Canberra.

Australian Crime Commission Act 2002, Part 1 - Preliminary, 4, Interpretation (1), <http://www.austlii.edu.au/cgi-bin/sinodisp/au/legis/cth/consol_act/ acca $2002289 /$ s 4. html query $=$ serious $\% 20$ and $\% 20$ organised $\% 20$ crime $>$ (accessed 31 January 2010).

Australian Institute of Criminology 2004, 'The worldwide fight against transnational organized crime', Australia-Technical and Background PaperNo. 9, AIC, Canberra.

Ayling, J, Grabosky, P \& Shearing, C 2009, 'Lengthening the arm of the law', Enhancing police resources in the twenty-first century, Cambridge University Press, Melbourne.

Carmody, T 2010, 'Criminal law', in G Bammer (ed.), Dealing with uncertainties in policing serious crime, ANU E Press, Canberra.

Dean, G \& Gottschalk, P 2007, Knowledge management in policing and law enforcement: foundations, structures, applications, Oxford University Press, Oxford.

Jarrett, R \& Westcott, M 2010, 'Quantitative risk', in G Bammer (ed.), Dealing with uncertainties in policing serious crime, ANU E Press, Canberra.

Kebbell, MR, Muller, DA \& Martin, K 2010, 'Understanding and managing bias', in G Bammer (ed.), Dealing with uncertainties in policing serious crime, ANU E Press, Canberra.

Lawrence, C 2010, 'Politics', in G Bammer (ed.), Dealing with uncertainties in policing serious crime, ANU E Press, Canberra.

Longford, S 2010, 'Consultancy to build capacity in dealing with uncertainty in law enforcement', in G Bammer (ed.), Dealing with uncertainties in policing serious crime, ANU E Press, Canberra.

Parliamentary Joint Committee on the Australian Crime Commission 2009, Inquiry into the legislative arrangements to outlaw serious and organized crime, Parliament of Australia, Canberra, <http://www.aph.gov.au/senate/ committee/acc_ctte/laoscg/index.htm> (accessed 31 January 2010).

Prenzler, T 2009, Police corruption: preventing misconduct and maintaining integrity, CRC Press, USA. 
Schloenhardt, A 2009, Inquiry into the legislative arrangements to outlaw serious and organized crime, submission to the Parliamentary Joint Committee on the Australian Crime Commission 2009, Parliament of Australia, Canberra, http://www.aph.gov.au/senate/committee/acc_ctte/laoscg/submissions/ sub01.pdf (accessed 31 January, 2010).

Smithson, M 2010, 'Understanding uncertainty', in G Bammer (ed.), Dealing with uncertainties in policing serious crime, ANU E Press, Canberra.

Sullivan, S 2007, 'The adversarial intelligence model', Journal of the Australian Institute of Professional Intelligence Officers, vol. 15, no. 3, p. 81.

Wilkinson, S 2010, 'The modern policing environment', in G Bammer (ed.), Dealing with uncertainties in policing serious crime, ANU E Press, Canberra. 